\title{
AlOHIP
}

\section{Veronika Konrádová}

\section{„Lidský“ a „božský““ život v X.knize AristotelovyEtiky Níkomachovy}

Tematizace dvojí podoby usilování o dobrý život, která je u Aristotela vepsána do rozlišení „lidského“ a „božského“ života, je jedním z jeho důležitých př́spěvků k etické diskuzi probíhající ve starověkém Řecku. V následujícím textu budu toto téma sledovat s ohledem na úzké sepětí mezi etikou a politikou, z něhož Aristotelovy analýzy vycházejí, a zaměřím se především na specifický vztah mezi politikou a filosofí́, který se v této souvislosti rýsuje $\mathrm{v} X$. knize Aristotelovy Etiky Nikomachovy. ${ }^{\mathrm{i}}$

\section{Dva nejlepši životy}

Aristotelovo rozlišení „lidského“ a „božského“ života, které se objevuje v závěrečné knize Etiky Níkomachovy, je zasazeno do kontextu hledání lidské blaženosti, tj. zdárného či štastného života (eudaimonia), které tvoří kostru etického zkoumání $\mathrm{v}$ tomto pojednání. ${ }^{i i}$ Úvodní vymezení blaženosti jako „činnosti duše zhlediska zdatnosti“ (Eth.

\footnotetext{
${ }^{\mathrm{i}}$ Tato studie tematicky vychází z příspěvku předneseného v rámci konference Filozofia a umenie žit', kterou pořádalo Slovenské filozofické združenie pri SAV 13.-14. listopadu 2013 ve Smolenicích. Zde ho předkládám v přepracované a rozššřené podobě.

ii K pojetí eudaimonia viz např. Lear, 2009.
} 
Nic.I,6,1098a17) je evokováno i v závěrečných pasážích v X. knize, které budou bezprostředním předmětem našeho zkoumání:

„Je-li blaženost činnost z hlediska ctnosti (energeia kat' aretén), rozumí se, že z hlediska ctnosti nejhodnotnější; a to jest asi ctnost toho, co je v nás nejušlechtilejší. At' jest to rozum, at' něco jiného, co, jak se zdá, přirozeně vládne a vede a má poznání věcí krásných a božských, at' samo jest božské, at’ ze všeho v nás jest božstvu nejbližší, bude jeho činnost ve shodě s vlastní ctností dokonalá blaženost. “ii

V návaznosti na toto vymezení pokračuje Aristotelés přesnějším rozlišením prŕíslušných činností a rozlišuje zde dva typy života, které tyto činnosti ztělesňují: na jedné straně je to život „podle rozumu“ (kata ton nún bios), dále označovaný jako život božský, na druhé straně život „podle ostatních ctnosti““ (kata tén alén aretén), dále označovaný jako život lidský. Rozlišení obou životů tak s sebou nese i odpovídající hodnotovou hierarchii:

„...nejlepší a nejpř́ijemnější každému jest to, co je mu přirozeně vlastní. Tedy pro člověka jest to život podle rozumu, poněvadž to jest nejvíce člověk. A tak tento život jest i v nejvyšší míře blažený. Na druhém místě teprve jest život podle ostatních ctností... “ii

${ }^{\mathrm{i}}$ Eth. Nic. X,7,1177a11-18, citace z Etiky Nikomachovy uvádím v českém překladu Antonína Kř́že.

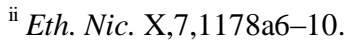


Toto rozlišení je dále podloženo poukazem na složenou povahu lidské přirozenosti, která v sobě zahrnuje jak složku emotivní, tak složku rozumovou. ${ }^{i}$ Dva typy životů tak ztělesňují dva typy blaženosti a na první pohled nečekaným způsobem zdvojují Aristotelovu odpověd' na otázku dobrého života, z níž celé pojednání vychází.

Aristotelés je v rozlišování obou typů blaženosti záměrně stručný a závěrečné pasáže Etiky Níkomachovy proto pochopitelně přitahují pozornost interpretů, a to zejména $\mathrm{z}$ těchto důvodů: celá Etika Níkomachova je zasazena do politického kontextu a zabývá se otázkami jednání $\mathrm{v}$ rámci lidského společenství, tj. $\mathrm{v}$ rámci polis. Úvodní pasáže explicitně zdưrazñují politické zakotvení etiky ${ }^{\text {ii }}$ a politický zájem na etické výchově.iii Podobně i její závěr umocňuje toto sepětí, když v poslední kapitole poukazuje na legislativní rámec etické výchovy, ${ }^{\text {iv }}$ a tím zároveň vytváŕí přirozený přechod $\mathrm{k}$ pojednání o politickém uspořádání, tedy k titulu Politika. Aristotelův zájem tedy, jak se zdá, směřuje primárně k politické oblasti. Jeho zkoumání se explicitně zaměřuje $\mathrm{k}$ oblasti praxis, tj. neusiluje o pouhé teoretické uchopení problému, ale mapuje prostor pro jednání a obrací se $\mathrm{k}$ těm, kteří se $\mathrm{v}$ tomto prostoru pohybují a aktivně vstupují do politického dění. ${ }^{\mathrm{v}} \mathrm{V}$ této sféře mají Aristotelovi posluchači uplatnit své kvality: „Ctnosti

\footnotetext{
${ }^{\mathrm{i}}$ Eth. Nic. X,8,1178a20-23.

${ }^{\text {ii }}$ Eth. Nic. I,2.

iii Eth. Nic. I,10; I,13.

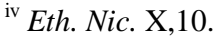

' Eth. Nic. I,1,1095a. Toto zacílení Etiky Nikomachovy zdůrazňuje např. O'Connor 1999, s. 109: „Aristotle's primary addressee is a man driven by ambition, an ambition that manifests itself fundamentally if not ultimately in politics. Aristotle issues an invitation to virtue that is aimed specifically at such ambitious men".
} 
praktického jednání tedy uskutečňují svou činnost v životě občanském nebo ve válce. ‘i

Vzhledem k tomu, že se Aristotelova etika takto zřetelně rozvíjí na půdorysu polis, můžeme etické zdatnosti, jimiž se Aristotelés zabývá, označit zároveň za politické zdatnosti a ,život podle ostatních ctností“ pak můžeme parafrázovat jako život politický. Naopak, ,život podle rozumu“ můžeme parafrázovat jako život teoretický či kontemplativní, tj. život filosofický. ii

Právě vyzdvižení teoretického života, s nímž přichází 7. a 8 . kapitola $v$ X. knize, kde se mu připisuje výslovný primát před životem politickým, však může v celku Aristotelova postupu působit překvapivě, rušivě či prŕmo paradoxně. Interpreti také nejsou při výkladu X. knihy jednotní a neshodují se v otázce vzájemného vztahu mezi oběma typy „,nejlepších životů“ ani v otázce celkové konzistence Aristotelova zpracování těchto motivů. Řada autorů zdůrazňuje tenze Aristotelova pojetí, iii přičemž interpretační návrhy k vyrovnání se s těmito tenzemi zahrnují celou škálu pozic. ${ }^{\text {iv }}$

\footnotetext{
${ }^{\mathrm{i}}$ Eth. Nic. X,7,1177b6-7.

ii Nedomnívám se však, že bychom toto označení mohli chápat jako vita contemplativa, at' už ve smyslu stř̌edověkého pojímání contemplatio nebo ve smyslu moderního rozlišení vita contemplativa / vita activa.

iii Viz např. Urmson 1995, s. 118-127; Nussbaumová 2003, s. 689-696.

iv Přehled bádání k této otázce nabízí Gottlieb, s. 195-196. Pokud jde o české bádání, nedávná studie z pera Stanislava Synka ponechává ve vztahu obou životů určité napětí: „....není jasné, zda je člověk spíše bytostí individuální, jejíž nejvyšší a nejsmysluplnější uskutečnění spočívá v soběstačné a na životě v obci jen minimálně závislé kontemplaci (theória), nebo zda je to spíše bytost „přirozeně“ společenská, jejíž štěstí závisí na štěstí druhých, a která jej proto nemůže dosáhnout bez „dobré“ či „št’astné“ společnosti ostatních lidí. Ukazují se tím meze celého Aristotelova konceptu: nemožnost sloučit
} 
V následujícím textu se pokusím zmírnit paradoxní vyznění závěru Etiky Nikomachovy a ukázat, že politika a kontemplace u Aristotela nestojí vedle sebe jako dvě disparátní aktivity, ale že jsou naopak spojeny velmi specifickým vztahem.

\section{Volba života?}

V první řadě se podívejme na to, zda Aristotelovo rozlišení „života podle rozumu“ (kata ton nún bios) a „života podle ostatních ctností“ (kata tén alén aretén) máme chápat jako rozlišení dvou životních alternativ, které by nás vybízely $\mathrm{k}$ volbě bud’ jedné, nebo druhé životní cesty, přičemž na jedné straně by se nabízel život zasvěcený aktivitě $\mathrm{v}$ rámci polis, $\mathrm{v}$ němž se osvědčuje široké spektrum etických zdatností, na druhé straně život zasvěcený kontemplaci a vzdálený politického dění. Tyto dva „životy“ jsou u Aristotela představeny jako seriózní kandidáti na dobrý život. Př́sně vzato je tu ještě jeden kandidát, a sice život zasvěcený slastem, ten je však u Aristotela degradován do pozice méně než lidského, spíše „dobytčího“ života. ${ }^{\mathrm{i}}$ Ačkoli tedy Aristotelés vychází z trichotomie životních alternativ přijímaných i v běžném mínění a zahrnujících požitkářský život, politický život a filosofický život, ${ }^{\mathrm{ii}}$ fakticky pracuje

lidskou a božskou perspektivu, a tím pádem i nemožnost uspokojivě odpovědět na výchozí otázku, co je skutečně vykonavatelné lidské štěstí.“ (Synek 2011, s. 239). Synek nicméně vzápětí připouští jistou dynamiku, kterou toto napětí vnáší do Aristotelova konceptu uskutečňování lidské přirozenosti.

${ }^{\mathrm{i}}$ Pokud jde o hodnotu slasti v lidském životě, je třeba poukázat na sofistikovanější analýzu v VII. a X. knize Etiky Nikomachovy.

${ }^{\text {ii }}$ Eth. Nic. 1095b17. Myšlenku trojího způsobu života odpovídající potrojné struktuře duše rozvíjí i Platón (Resp. 436a-441c, srv. Resp. 586a-e). 


\section{AlOHP}

s dichotomií politického a filosofického života. Stojí však před námi oba členy této dichotomie jako předměty životní volby? Lze volit jeden před druhým?

K této otázce můžeme nejprve předeslat, že motiv volby životní cesty je $\mathrm{v}$ antické tradici dobře znám a dostalo se mu vícerého literárního zpracování. Jedním z př́kladů může být Prodikova alegorie Héraklés na rozcestí, kde se nabízené alternativy, mezi nimiž se má Héraklés na prahu dospělého života rozhodnout, rozevírají mezi pohodlným požitkářským životem a životem založeným na zdatnosti, provázeným však námahou a úsilím. ${ }^{i}$ Prostor tomuto motivu dává také Platón, který otázku volby života navozuje v dialozích Gorgias, Obrana Sókrata či Ústava. V Obraně Sókrata je rozlišeno dvojí životní úsilí: jedno zaměřené na peníze, pověst a čest, druhé zaměřené na rozum a pravdu a usilující o kultivaci duše. ${ }^{\mathrm{ii}} \mathrm{V}$ Gorgiovi je explicitně položena otázka, jakým způsobem je třeba žít, a jsou rozvrženy dvě životní možnosti, jejichž nároky musíme se vší zodpovědností zvážit: na jedné straně život věnovaný aktivnímu působení v politické sfére, v níž se k činům pojí čest a uznání, na druhé straně život věnovaný filosofii. iii $\mathrm{S}$ př́żnačnou naléhavostí je pak motiv volby života zakomponován do závěrečného líčení v desáté knize Ústavy. Zde zastihujeme duši člověka na prahu nového zrození, kdy je postavena před nutnost zvolit si nikoli jednu ze dvou alternativ, ale vybrat si z celého spektra možných životů. Tato volba

\footnotetext{
${ }^{\mathrm{i}}$ Xenofón, Mem. 2.1.21-34. Předobrazem je pasáž z Hésiodovy skladby Práce a dny (Hésiodos, Op. 287-292).

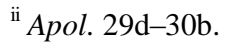

iii Gorg. 500b-d.
} 
je nezvratná a se vší vážností člověka jednou provždy činí zodpovědným za to, kým je. ${ }^{\text {i }}$

Pro další rozvíjení našeho tématu je vhodné již na tomto místě poznamenat, že Platón zde zároveň poukazuje na vážná úskalí této prekérní situace, do níž se duše dostává. Volba životního osudu může být vykonána zaslepeně a zbrkle, jak se to prŕznačně ukazuje hned u prvního volitele, který nerozvážně sáhne po životu tyrana, protože včas neprohlédne hrůzné skutky, jež takový život provázejí. Přitom je velmi výmluvné, že tuto neblahou volbu provádí duše člověka, který žil svůj předchozí život slušně, ale - a to je klíčové - byla to slušnost založená pouze na zvyku, nikoli na filosofickém pochopení. ${ }^{\text {ii }}$

Vrátíme-li se zpět k Aristotelovi, můžeme se z této perspektivy ptát, zda bychom měli ve světle zde naznačené textové tradice číst i X. knihu Etiky Níkomachovy. Nabízí se politický a filosofický život jako alternativy pro volbu životní cesty? Domnívám se, že takové čtení by bylo nepřesné, a to zejména pokud uvážíme Aristotelovo chápání volby. Aristotelés se v rámci svého etického uvažování otázkou volby (prohairesis) široce zabývá, nicméně nepracuje s výše naznačenou představou absolutní volby, která by zavazovala celou naši existenci, ale spíš s představou volby relativní - ve své koncepci tedy podržuje moment přednostní volby, která předpokládá vybírání a předchozí zvažování. ${ }^{i i i} \mathrm{Ve}$ III. knize Etiky Nikomachovy proto opakovaně zdůrazňuje, že volba se týká prostředků, nikoli cílů. Volíme tedy prostředky či způsoby určitého jednání, ale nikoli samotný cíl, pro který jednáme. Ovšem volba života by právě byla volbou cíle. Na rozdíl od platónské vize, která říká „podle

\footnotetext{
${ }^{\mathrm{i}}$ Resp. 617d-621b.

ii aneu filosofias, Resp. 619d1.

iii Viz Nussbaumová 2003, s. 586nn.
} 
toho, jaký život si každá duše zvolí, takovou se nutně stává“, í tedy Aristotelés předpokládá, že předmětem volby jsou konkrétní způsoby jednání, a ty jsou potom konstitutivní pro lidský charakter. ii Tomu odpovídá i posun $\mathrm{v}$ chápání zodpovědnosti za to, jaký život vedeme. $\mathrm{V}$ aristotelské perspektivě nejsme tím, „,o si jednou provždy volíme být, ale tím, co si v každém okamžiku volíme dělat ${ }^{\text {“ iii }}$

Rozlišení životních perspektiv

S tímto upřesněním můžeme postoupit ke zvážení hodnoty obou způsobů života a ptát se, podle jakých kritérií je rozlišujeme. Vyjděme z Aristotelovy otázky, ${ }^{\text {iv }}$ zda je pro zdatnost důležitější záměr, resp. záměrná volba (prohairesis), nebo činy (praxeis). Aristotelés tuto otázku sám zodpovídá opakovaným poukazem na to, že o povaze etického jednání rozhoduje především záměrná volba: „zdá se totiž, že jest ctnosti nejvlastnější a že o mravní povaze rozhoduje více než skutky samy. “v V tomto přesvědčení je zakódováno rozlišení mezi vnějším a vnitřním charakterem jednáním a Aristotelés jej na více místech demonstruje napřr. upozorněním, že nestačí konat spravedlivé činy, ale je třeba tyto činy konat jako člověk spravedlivý, to znamená jako ten, kdo se rozhoduje

\footnotetext{
${ }^{\mathrm{i}} \operatorname{Resp} .618 \mathrm{~b}$.

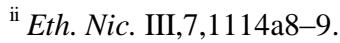

iii Aubenque 2003, s. 152.

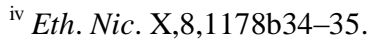

${ }^{\mathrm{v}}$ Eth. Nic. III,4, 1111b5; srv. 1112a2-3.
} 
a jedná se zřetelem k principům etického jednání. ${ }^{\mathrm{i}}$ Podmínky eticky hodnotného jednání jsou přesněji vymezeny takto:

„...v oboru mravnosti jednání nebývá provedeno spravedlivě nebo uměřeně, má-li jen nějakou vlastnost, nýbrž teprve tehdy, je-li v nějakém stavu ten, kdo jedná, předně jedná-li vědomě, potom podle svobodného rozhodování, a to rozhodování zaměřeného na mravní jednání samo, a za třetí, jedná-li pevně a stále. ‘ii

Povaha etického jednání je přitom založena skrze rozumnost, fronésis, tj. skrze schopnost nalézat $\mathrm{v}$ proměnlivých konstelacích našeho života optimální způsob, jak odpovídat na výzvy situací, v nichž se $\mathrm{v}$ životě ocitáme. Ve struktuře jednání pak spolupůsobí jak schopnost nacházet přiměřené zpo̊soby chování, tak schopnost orientovat tyto způsoby vůči celkovému směřování našeho života: zdatnost je odpovědná za směřování ke správnému cíli, rozumnost pak ve světle tohoto cíle volí správné prostředky, které k němu vedou. iii Podotýkám že „prostředky“ zde míníme především konkrétní způsoby jednání, které v jednotlivých situacích specifickým způsobem ztvárňují naši představu o tom, jak bychom měli jednat, aby náš život byl zdárný.

Rozlišení mezi záměrnou volbou a činem Aristotelovi především umožňuje ostřeji vykreslit povahu etického jednání a vymezit jej vůči činnostem, které nemají povahu praxis, ale povahu techné. Výkon techné

\footnotetext{
${ }^{\mathrm{i}}$ Eth. Nic. II,3,1105a30-1105b9; srv. Eth. Nic. VI,13,1144a13-21.

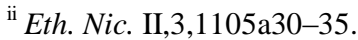

iii Eth. Nic. VI,13,1144a8-9. K této otázce srv. Moss 2011.
} 


\section{AIOHP}

hodnotíme na základě provedení určitého díla, etické jednání však posuzujeme nejen podle vnější podoby příslušného činu, ale především podle toho, jaká vnitřní dispozice je ztvárněna $\mathrm{v}$ aktuálních volbách jednajícího. ${ }^{\mathrm{i}}$

Vrací-li se Aristotelés k těmto konstituentům zdatnosti v X. knize a ptá-li se znovu, jakou roli zde má záměrná volba a jakou samotný čin, může být takto postavená otázka důležitým vodítkem pro uchopení vztahu mezi filosofickým a politickým životem, protože různé odpovědi na ni otevírají různé perspektivy, z nichž lze tento vztah nahlížet. Z perspektivy činů se politický a filosofický život liší svým obsahem, liší se povahou vykonávaných činností. Rozdíl obou způsobů života by $\mathrm{z}$ tohoto hlediska spočíval $\mathrm{v}$ odlišnosti životních náplní. Vnější podoba jednání však, jak jsme viděli, není jediným kritériem. Činnosti lze posuzovat nejen $\mathrm{z}$ hlediska toho, co děláme, ale také $\mathrm{z}$ hlediska toho, jakými principy se ř́díme při jejich vykonávání, tedy kvưli čemu jednáme. Zavedení hlediska účelů a cílů pak dovoluje odlišně strukturovat i vztah mezi politickým a filosofickým životem. Odlišujícím znakem potom nebude rozdílná životní náplň, ale celkové zaměření života.

Politický život by z tohoto hlediska mohl být charakterizován jako život zaměřený na široké spektrum jednotlivých etických zdatností uplatňovaných v rámci společenského soužití, filosofický život, tj. život vedený z pozice theória, by oproti tomu nabízel vyšší míru integrace jednotlivých činností do celku života a vztažení těchto činností $\mathrm{k}$ jednotě št’astně vedeného života. ${ }^{\text {ii }}$

\footnotetext{
${ }^{i}$ K analýze jednání srv. Čapek 2007, s. 83-104; Kontos 2006; Synek 2011.

ii „In the political life, the dominant attention and value remains with the individual virtuous actions. The contemplative life places attention and value on the single happy life made up of these parts. When many good actions are fully integrated into one happy life,
} 
Domnívám se, že toto rozlišení může napomoci k méně vyhrocené interpretaci Aristotelova chápání vztahu mezi politickým a filosofický životem a nabídnout pojetí politiky a filosofie jako dvou př́stupů či perspektiv, s nimiž lze k vlastnímu životu přistupovat - jednou z hlediska mnohosti různých typů jednání, jímž se lze angažovat ve společenském prostoru, jednou se zřetelem k jednotícímu momentu, jímž je náš život reflexivně svazován do koherentního celku.

To, co se z vnějšku jeví jako ten samý život, tedy může být vedeno bud' filosoficky, nebo politicky - to záleží na porozumění jednajícího. Rozdíl mezi politickým a filosofickým životem by se potom nezakládal na odlišném obsahu př́islušných životů, ale na odlišných perspektivách, z nichž člověk své konání nahlíží. Nejde tedy o rozlišení dvou odlišných typů života, ale spíš o rozlišení dvou způsobů, jak přistupovat ke svému životu, spolupř́tomných v konkrétním životě jedince. $^{\mathrm{i}}$

then one is living theoretically..." (Garver 2006, s. 196). Rozlišení obou hledisek, z nichž lze nahlížet vztah mezi politickým a filosofickým životem, lze ostatně vztáhnout i na situaci autora či čtenáře tohoto textu: je náš život více filosofický právě tady a ted', když se věnujeme filosofickým tématům a úvahám a nefilosofický tehdy, když se zaobíráme rozličnými povinnostmi $\mathrm{v}$ rámci našich běžných pracovních, společenských a domácích aktivit, nebo může být náš život filosofický právě v tom smyslu, že rozumíme našim aktivitám z hlediska života jako celku a dokážeme je vztahovat k určité jednotící perspektivě?

i „Note that on the interpretation of 10.6-8 as giving an outline of happiness, we do not take the phrases 'a life lived according to the mind (or philosophical wisdom)' (1177b30) or 'a life lived according to the other virtues' (1177a21) to mean separate ways of life, or possible bibliographies, but rather ways of carrying on with life, which coexist in the life of one individual.“ (Pakaluk 2005, s. 327). Pakaluk bezprostředně navazuje objasněním, jak si představuje tuto koexistenci: „Aristotle when lecturing in philosophy is living 'life according to the mind,' and when he is writing his will, and exercising administrative 
Toto rozlišení dvou momentů spoluprítomných $\mathrm{v}$ jednom životěi dobře koresponduje súvahami o štastném či blaženém životě, tj. o eudaimonia. K formálním charakteristikám eudaimonia patř́ „dokonalost" a „,soběstačnost“: ,jeví se tudíž blaženost něčím dokonalým a něčím soběstačným, poněvadž je cílem všeho konání. “iii Nabízí se otázka, v jakém smyslu může být náš život dokonalý a završený tak, aby se v něm osvědčila kvalita eudaimonia. Můžeme tuto završenost či úplnost chápat v časovém smyslu, což je možnost, kterou Aristotelés prověřuje v první knize Etiky Nikomachovy, kde ale zároveň vyzdvihuje zjevné paradoxy, v nichž se tato časová perspektiva nutně ocitá: za štastně žijícího bychom mohli člověka označit nikoli za jeho života, ale až po smrti, kdy definitivně uniká možným zvratům osudu, nicméně i po smrti na něj mohou doléhat neblahé prŕhody potomků, atd. Spíše se proto nabízí vztáhnout eudaimonia k jinému typu celostního uchopení života. Opět můžeme vyjít z rozlišení mezi techné, jakožto instrumentální činností směřující k nějakému vnějšímu výsledku, a praxis, jako činnosti vykonávané s vědomím účelu a plným uvědoměním aktivity samotné, v níž účel nespočívá ve vnějším „díle“, ale v této činnosti samé.

Uvědomujeme si, že náš život není nikdy kompletně završen v podobě dokonalé aktualizace a neleží před námi jako hotové „dílo“. Nacházíme se spíš na cestě $\mathrm{k}$ této aktualizaci a $\mathrm{v}$ tomto smyslu je náš život spíš směřováním, nikoli naplněním. Přesto můžeme být schopni pohlédnout na náš život jako celek. Takto kompletního náhledu můžeme

virtue and justice, he is living 'life according to the other virtues.' Those phrases should be taken to indicate types of activity." (Pakaluk 2005, s. 327).

${ }^{\mathrm{i}} \mathrm{V}$ tomto smyslu člověk uplatňující etickou zdatnost a člověk oddávající se kontemplaci „nejsou dvě odlišné osoby, spíše jedna a táž osoba na různých úrovních znamenitosti.“ (Aubenque 2003, s. 98).

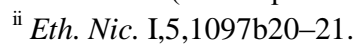


nejlépe dosáhnout v jistých sebereflexivních aktech umožňujících určitý intelektuální nadhled nad tím, co děláme. ${ }^{i}$ Teprve tato sebereflexe provázená sebeuvědoměním vnáší do života potřebnou stálost a jednotu: „blažený člověk ... po celý život zůstane takový, jaký jest; nebot' vždy, anebo především, v jednání a v zkoumání bude hleděti $\mathrm{k}$ tomu, co jest ctnostné (praxei kai theórései ta kat'aretén)..." “ii

V uvedené formulaci je výslovně podtrženo sepětí mezi praxis a theória a Aristotelés s tímto sepětím i nadále pracuje, když v IX. knize jako prríhodný předmět theória určuje nejen naše vlastní skutky, ale ještě více skutky přátel, $v$ nichž jakoby vidíme sami sebe: ${ }^{\text {iii }}$

„Jestliže blaženost záleží v žití a ve skutečné činnosti a činnost dobrého člověka, jak jsme poznamenali na začátku, jest dobrá a př́ijemná sama o sobě, a jestliže dále každému je př́ijemné to, co jest mu vlastní, a můžeme-li konečně snáze pozorovati své bližní a jejich skutky než sami

\footnotetext{
i „,...jestliže dále ten, kdo vidí, pocit'uje, že vidí, a ten, kdo slyší, pocit'uje, že slyší, a ten, kdo jde, že jde, a tak i při ostatních činnostech jest něco, čím pocit’ujeme, že jsme činni, takže pocit'ujeme, že pocit'ujeme, a myslíme, že myslíme, a to jest zase tolik, jako pocit'ovati nebo mysliti, že jsme - nebot' býti jest tolik, jako pocit'ovati nebo mysliti..." (Eth. Nic. IX,9,1170a29-b2).

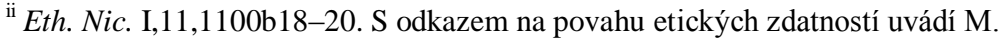
Pakaluk: „their being goals somehow involves our being able to reflect upon or see them with reasonable satisfaction; this is not philosophical contemplation strictly, but some kind of intellectual perception, presumably of the kalon, namely what is admirable and attractive in action. It must be Aristotle's view ultimately that to carry out a fitting action is somehow to see that it is fitting, and that our seeing that it is so is the best part of the action, and that there is no point to life beyond seeing in this way." (Pakaluk 2005, s. 328). Srv. Rorty 1978 , s. 346.

iii K širšímu kontextu viz Eth. Nic. IX,9,1169b15-1170a5. K politickému charakteru přátelství srv. Garver 2006, s. 141.
} 


\section{AIOHP}

sebe a své skutky, vyplývá z toho, že skutky ctnostných prátel jsou lidem dobrým př́ijemné - nebot' pak oba mají to, co jest prrirozeně př́ijemné -: tedy blažený člověk bude takových prátel potřebovati, ježto si přeje pozorovati dobré skutky, jak jemu jsou vlastní, a těmi jsou skutky člověka dobrého, je-li př́telem. “i

Je-li takto pojat rozsah předmětů nabízejících se ke kontemplaci, lze $\mathrm{v}$ tom zároveň spatřovat vodítko $\mathrm{k}$ lepšímu pochopení, $\mathrm{v}$ čem by mohla spočívat theória, označená v desáté knize za nejvyšší a nejvíce božskou činnost.

Víme, že božský život spočivá v myšlení sebe sama. Která lidská aktivita by potom byla nejvíce božská? Mohlo by to být myšlení o božském, takže bychom se snažili co možná nejvíce nahlížet to samé, co nahlíží bůh. Toto pojetí theória by nejspíš odpovídalo Aristotelově Metafysice a hodnota teoretické činnosti by se tu odvozovala od hodnoty

\footnotetext{
${ }^{\mathrm{i}}$ Eth. Nic. IX,9,1169b31-1170a4. Úlohu přátelství v souvislosti s vědomím sebe samého dále rozvijí pasáž, již pokračuje výše uvedený citát v pozn. clxxx: „...jestliže dále pocitovati, že žijeme, jest o sobě něco prřijemného - nebot' život jest přirozeně dobro, a pocit, že dobro jest $v$ nás, jest př́ijemný -, jestliže kromě toho život jest žádoucí a zvláště lidem dobrým, poněvadž býti jest jim něčím dobrým a př́ijemným - těší se totiž z vědomí dobra samého o sobě -, jestliže se konečně ctnostný člověk chová $\mathrm{k}$ př́iteli - nebot' př́tel jest jeho druhé já - tak, jako se chová $\mathrm{k}$ sobě, tedy z toho všeho vyplývá, že jako každému jest žádoucí jeho vlastní bytí, tak anebo alespoň podobně jest mu žádoucí i bytí prítelovo. Bytí však jest nám žádoucí proto, že jsme si vědomi dobra ve své bytosti; takové vědomí pak jest př́jemné samo o sobě; proto jest potřebí také míti vědomí o jsoucnosti př́telově, a to se může stát ve společném žití výměnou slov a myšlenek.“ (Eth. Nic. IX,9,1170b212).
} 
jejího předmětu. ${ }^{i}$ Položíme-li však dưraz na reflexivní moment theória, který zaznamenáváme v Etice Nikomachově, může se jako nejvíce božská činnost, přibližující se tomu, co dělá bůh, ukázat myšlení o našich vlastních aktivitách - podobně jako bůh nahlíží sám sebe, nahlíželi bychom i my naši vlastní činnost. Teprve v tomto smyslu by mohlo být to, co je božské, zároveň tím, co je nám nejvlastnější.

Domnívám se tedy, že plausibilní interpretace by měla spojit oba zmíněné kroky: jednak rozšiřrit pole kontemplace tak, aby obsáhla širší spektrum možných předmětů, ii jednak zároveň korigovat chápání Aristotelova konceptu homoiósis theó, tedy konceptu nápodoby božského, který je důležitým fundamentem Aristotelova etického uvažování. Z perspektivy Etiky Nikomachovy se ukazuje, že tato nápodoba nemusí být striktní nápodobou božské aktivity $\mathrm{v}$ čistě inteligibilní sfére, v níž se bůh jakožto čistý rozum vztahuje $\mathrm{k}$ nejhodnotnějším předmětům myšlení, ale může být nápodobou právě oné reflexivity, s níž je theória v kontextu Etiky Nikomachovy spojena.

Fronésis a theória

Takto pojatou kontemplaci potom ale není třeba stavět proti politickému životu jako možnost nějakého ,jiného“, apolitického života. Tímto směrem poukazuje i Aristotelova polemika s názorem, že filosofie

\footnotetext{
i Theória, v nejširším smyslu „vidění“ či „,nahlížení“, označuje dokonalé vědění vztahující se k nutným a neměnným předmětům.

ii Jistou volnost tu naznačuje i Aristotelés, když v závěru 8. kapitoly X. knihy uvádí, že „blaženost jest jakési rozjímání“ (theória tis). Zdá se, že tu tedy nemá na mysli striktně pojatou theória v duchu Metafysiky.
} 
znamená ústup z aktivního života do ústraní a neaktivity, naznačená v VII. knize Politiky. ${ }^{\mathrm{i}}$ Aristotelés k tomu ř́íká:

„Ale není nutno, aby ten, kdo je činný, byl činný vzhledem k jiným, jak se někteří domnívají, ani aby prakticky činné bylo jen myšlení, které přihlíží k výsledku jednání, nýbrž praktický význam v mnohem větší míře mají rozjímání a myšlenky, které mají účel samy v sobě a jsou samy pro sebe.“ ii

Klíčový je zde důraz na aktivitu, která může mít jak vnější, tak vnitřní charakter. Aristotelés tuto dvojí aktivitu vztahuje k jednotlivci i k obci a uvádí ji v paralele s božskou činností:

„Podobně je tomu také u kteréhokoli jednotlivého člověka; sice by se Bůh a vesmír sotva měl dobře, kteří mimo své vlastní činnosti zevnější činnosti nemají، ‘iii

$S$ přihlédnutím k těmto vyjádřením můžeme postoupit k přesnějšímu vymezení vztahu mezi teoretickou a politickou aktivitou.

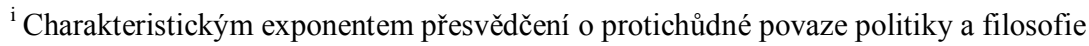
a zastáncem teze o neaktivní, a v tomto smyslu ,nemužné“ povaze filosofie může být Kalliklés z Platónova dialogu Gorgias (Gorg. 485c-486d).

ii Pol. VII,3,1325b18-22.

iii Pol. VII,3,1325b28-30.
} 
Namísto ostré distinkce mezi kontemplativním a politickým životem můžeme spíše říci, že kontemplace završuje politický život a sama je již v politickém životě založena: politická přirozenost člověka, vystižená označením zóon politikon, je podmíněna schopností řeči a myšlení, kontrahované ve formuli zóon logon echon. ${ }^{i}$ Obě označení mimo jiné podtrhují politický charakter přátelství, které skrze reflexi skutků druhého, onoho „druhého jác, s nímž prodléváme ve společné „výměně slov a myšlenek“" ii umožňuje naši vlastní sebereflexi a uvědomění si vlastní areté. Obě společně pak ukazují, nakolik je lidská racionalita svázaná s politickou přirozeností člověka. Prostor polis je také tím, kde se tato racionalita primárně projevuje. Široké spektrum lidského konání vyžaduje fronésis, která je pro dobrý život nezbytná, nebot' tvoří racionální strukturu etické zdatnosti. ${ }^{\text {iii }}$

Jakožto schopnost vztahovat se k obecnému i jednotlivému, umožňující nacházet konkrétní způsoby osvědčení etické zdatnosti ve světle obecných principů, je pak právě fronésis důležitou spojnicí mezi praktickým a teoretickým rozumem. V tomto smyslu také připravuje půdu pro rozvinutí theória: „rozumnost není nadřizená moudrosti ani vyšší stránce rozumové ... nebot' ji nepoužívá, nýbrž hledí $\mathrm{k}$ tomu, jak by vznikla: přikazuje tedy pro ni, ale nikoli jí. ‘iv

V jakém smyslu je tedy theória podmíněna schopností etického jednání v rámci polis? Pouze ten, kdo disponuje fronésis, dokáže posoudit relativní hodnotu lidských aktivit, ale především rozumí činnostem vykonávaným pro ně samé - nahlíží tedy rozdíl mezi činnostmi, které

\footnotetext{
${ }^{\mathrm{i}}$ Pol. I,2,1253a10-18.

${ }^{i i}$ Eth. Nic. IX,9,1170b.

iii Eth. Nic. X,8,1178a10-19.

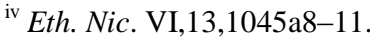




\section{AlOHP}

mají charakter energeia, a činnostmi, které mají charakter kinésis, a z této perspektivy také pohlíží na etické jednání. Aktivita chápaná podle modelu kinésis má povahu instrumentální činnosti a její cíl leží vně této aktivity samé. ${ }^{i}$ Naproti tomu aktivita chápaná podle modelu energeia je sama v sobě svým cílem a právě takovou aktivitou je etické jednání, alespoň ve své ryzí podobě.

Zde se otevírá prostor pro rozlišení prosté zdatnosti, která je nutná pro dobrý život a která s sebou nese žádoucí doprovodné momenty jako čest, moc či sociální postavení, a ušlechtilosti, která si cení zdatnosti a vykonávání zdatnosti pro ni samu, tj. pro její vnitřní hodnotu. ${ }^{\mathrm{ii}}$ Právě tímto směrem se ubírají subtilní analýzy povahy zdatnosti, v nichž Aristotelés jemněji rozlišuje mezi eticky a politicky motivovanou zdatností - př́́kladem může být jeho analýza statečnosti ve III. knize Etiky Nikomachovy, kde uvádí, že politická statečnost bojovníka v občanském vojsku se sice nejvíce podobá statečnosti, ale ryzí statečností není, a to právě díky tomu, nakolik je motivována vedlejšími principy $\mathrm{v}$ podobě veřejného uznání a ocenění nebo pouze poslušností vůči zákonu. ${ }^{\text {iii }}$ Principiálním vyjádřením tohoto postřehu je upozornění, že zdatnost není pouze kata ton orthon logon, ale meta tú orthú logú. ${ }^{\text {iv }}$

Posun mezi oběma pozicemi, mezi politicky a eticky motivovanou zdatností, je dílem etického vývoje. Během tohoto vývoje může být spektrum dílčích jednání vyplňujících politický prostor vnímáno nikoli jako prostý součet činností skládajících dobrý život, ale může být

\footnotetext{
${ }^{\mathrm{i}}$ Srv. rozlišení zdatnosti a dovednosti (deinotés) v Eth. Nic. VI,13,1144a.

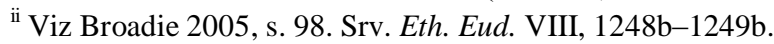

iii Zde můžeme rovněž navázat poukazem na rozlišení zvykové a reflektované zdatnosti, které je sókratovsko-platónským dědictvím a které bylo výše navozeno odkazem na eschatologický mýtus v Resp. X.

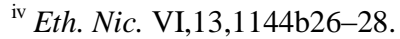


pozvednuto k nahlížení vnitřní hodnoty zdatnosti a vztaženo k jednotící perspektivě dobře vedeného života jako celku, pojímaného rovněž ve smyslu energeia. K tomu má člověk disponující fronésis již všechny předpoklady.

Z povahy lidské bytosti dále vyplývá, že vyšší míra jednoty je u ní dána vyšší mírou integrace různorodých komponentů. ${ }^{i}$ Jednota lidského života proto nespočívá ve vykonávání stále téhož: „kdyby naopak přirozenost bytosti byla jednoduchá, bylo by jí vždy totéž jednání největší slastí. “iii Tak tomu ale u člověka není. Složená lidská přirozenost nachází svou jednotu ve vyšší míře integrace sjednocující rozmanité činnosti. ${ }^{\text {iii }} \mathrm{Na}$ rovinu života jednotlivce tak lze přenést postřeh, který se u Aristotela uplatňuje i na rovině politického života: i zde je jednota pojata ve smyslu integrace mnohosti a mnohotvárnosti, jak Aristotelés polemicky zdůrazn̆uje v kontrastu vůči platónské vizi.

K výše uvedeným zásadám aristotelské antropologie je proto tř̌eba dodat ještě další upozornění, které říká, že „,̌̌lověk není tím nejlepším ve vesmíru. “iv Jeho lidské, společensky uplatňované aktivity, jakkoli dosahují své vlastní dokonalosti, jsou přece co do hodnoty druhé v pořadí. ${ }^{v}$ Tvoří však nezbytnou podmínku pro integrující teoretický náhled nad těmito aktivitami. Kontemplativní život se proto nevyvazuje

\footnotetext{
${ }^{\text {i }}$ Připomeňme Aristotelovy analýzy jednoty v Metafysice, kde je jednota hromady konfrontována s vyšší jednotou integrovaného celku (Met. X,1,1052a).

${ }^{\text {ii }}$ Eth. Nic. VII,15,1154b25-26.

iii I k tomuto by měl být disponován již fronimos: právě on ví, že izolované činy bez koherence a kontinuity nezakládají dobrý život (viz Eth. Nic. II,3,1105a30-35).

${ }^{\text {iv }}$ Eth. Nic. VI,7,1141a21-23.

' Proč nestačí žít život založený na fronésis? A. Rorty k tomu uvádí: „Theoria can complete and perfect the practical life, making it not only self-justified but self-contained because its grounds are contained within it." (Rorty 1978, s. 350).
} 


\section{AlOHP}

ze společenských vazeb, jak je výslovně zdůrazněno opakovanými poukazy na to, že pospolitý život je pro blaženost nezbytný. ${ }^{i}$ Soběstačností blaženého života se tudíž nemíní život samotářský:

„....dokonalé dobro dostačuje samo sobě. Tím však nemíníme, že něco jest soběstačné jen pro jednoho člověka, který žije život samotářský, nýbrž i pro rodiče, děti a ženu a vůbec pro prátele a občany, poněvadž člověk jest přirozeně určen pro život v obci. “ii

Domnívám se proto, že na základě předložené evidence je možné zmírnit napětí v Aristotelově konceptu politického a filosofického života, a tím zároveň podpořit koherentnější čtení závěru Etiky Nikomachovy. Ukázalo se, že oba způsoby života, nebo lépe řečeno obě životní perspektivy, nestojí vedle sebe jako předměty alternativní volby, ale jsou spojeny fundamentálnějším vztahem. Jednotícím prvkem Aristotelova pojetí je přitom prvek aktivity, aktivně pojímaného života. Pojetí života jako energeia je navozeno již argumentací v 6. kapitole I. knihy, kde Aristotelés hledá ergon člověka, tj. specifický výkon, který náleží konat člověku jakožto člověku. iii Aristotelés zároveň ukazuje, že tento aktivní, en-ergický náboj v sobě nese nejen politická angažovanost, ale v ještě vyšší míře teoretická činnost.

\footnotetext{
${ }^{\mathrm{i}}$ Eth. Nic. IX,1169b15-1170a5; srv. 1157b21; 1099b4.

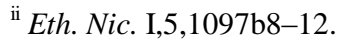

iii Protipólem aktivního výkonu života je nečinnost srovnatelná s pasivitou spícího člověka, což je obraz, kterým Aristotelés své rozlišení opakovaně podtrhuje (Eth. Nic. I,5,1095b33-1096a2; I,8,1098b33-1099a8; X,8,1178b19-20).
} 
Předložená analýza souzní i s aristotelským pojetím etického zdokonalování, tedy s pojetím výchovy, v níž se uplatňuje princip postupného progresu. Prostorem pro výchovu je v první řadě polis. Opět můžeme připomenout, že etické zdatnosti jsou především politickými zdatnostmi, protože sebevláda, tj. stav, kdy si člověk rozumí jako jednajícímu a volí jednání pro ně samo, se rozvíjí skrze podřízení politické vládě. ${ }^{i} \mathrm{Ve}$ vztahu k rozumu to znamená, že se člověk učí poslouchat vlastní rozum takovým způsobem, že nejprve poslouchá a podřizuje se rozumu ostatních - jako dítě rozumu dospělých, jako dospělý především rozumu zákona. ${ }^{\text {ii }}$ Zprvu pouze potenciálně rozumné jednání se tak skrze habituaci a následnou reflexi může stát plně rozumným jednáním, kterému jednající člověk rozumí jako jednání dobrému a krásnému.

Zvykovost je důležitým stupněm etického vývoje, není však jeho konečným stupněm. ${ }^{\text {iii }}$ Aristotelovy analýzy ponechávají prostor pro postupné zlepšování, v němž hraje klíčovou roli lepší porozumění etické motivaci, a toto porozumění se odvíjí od rozumové reflexe. Právě toto porozumění pak otevírá cestu k výše sledovanému uskutečňování vlastního života jakožto energeia. Podstatné založení theória v prostoru politického života, které se předložená interpretace snažila sledovat, tedy zároveň zhodnocuje ústřední Aristotelovu tezi o politickém zakotvení

\footnotetext{
${ }^{i}$ Garver 2006, s. 130. Naopak jednotlivé špatnosti znemožňují občanskou participaci, protože skrze ně se lidé stávají př́iliš otrockými nebo př́liš despotickými, takže se nemohou účastnit politického stř́idání vládnutí a podřizování se vládě.

ii Zákon je ,rozum bez žádostivosti“, jak uvádí Aristotelés v Politice (Pol. III, 16,1287a33).

iii Srv. Nussbaumová 2003, s. 551-553.
} 


\section{AIOHP}

-AIEIP

lidského života, stejně jako tezi o trvání polis ,za účelem života dobrého“. i

\section{Abstract}

The paper analyzes two forms of pursuit of the good life, which are inscribed in Aristotle's distinction between the "human" and the "divine" life. This topic is pursued with regard to the close links between ethics and politics, on which Aristotle's analyzes are based, and focuses on the specific relationship between politics and philosophy, which is in this context outlined in the X. book of Aristotle's Nicomachean Ethics. The distinction between the political and the philosophical life is interpreted not as determination of two distinct contents of life, we have to choose between, but as a determination of two approaches or perspectives from which we can access to our own lives - either in terms of a multiplicity of different types of behavior in the social space or with a view to a unifying moment, which ties our lives reflexively into a coherent whole. Taking into account the relevant principles of Aristotelian anthropology the paper shows that this conception of philosophical contemplation is founded already in the political life, and therefore doesn't stand against it as a variant of some "other" life deprived of the socio-political bonds. The proposed interpretation allows to mitigate the tensions in Aristotle's concept of political and philosophical life, and thereby encourage a more coherent reading of the end of the Nicomachean Ethics.

\footnotetext{
${ }^{\mathrm{i}}$ Pol. I,2,1252b30.
} 
AlOHI

_AlOIP 


\section{AIOHP}

\section{Bibliografie:}

Aristotelés, 1996, Etika Nikomachova, přeložil Antonín Kříž, Praha.

Aristotelés, 2003, Metafysika, přeložil Antonín Kříž, Praha.

Aristotelés, 1998, Politika, přeložil Antonín Kříž, Praha.

Aubenque, P., 2003, Rozumnost podle Aristotela, Praha.

Barney, R., 2005, „Comments on Sarah Broadie 'Virtue and beyond in Plato and Aristotle'“, The Southern Journal of Philosophy 43, s. 115-125.

Broadie, S., 2005 „Virtue and beyond in Plato and Aristotle“, The Southern Journal of Philosophy 43, s. 97-114.

Čapek, J., 2007, Jednání a situace, Praha.

Garver, E., 2006, Confronting Aristotle's Ethics: Ancient and Modern Morality, Chicago.

Gotlieb, P., 2009, The Virtue of Aristotle's Ethics, Cambridge.

Hésiodos, 1990, Zpěvy železného věku, přeložila Julie Nováková, Praha.

Kontos, P., 2006, „Morální jednání u Aristotela“, in: Švec, O. (ed.) Filosofie jednání, Praha, s. 49-61.

Lear, G. R., 2009, „Happiness and the Structure of Ends“, in: Anagnostopoulos, G. (ed.) A Companion to Aristotle. 


\section{AlOHIP}

Nussbaumová, M., 2003, Křrehkost dobra. Náhoda a etika v řecké tragédii a filosofii, Praha.

Moss, J., 2011, „'Virtue Makes the Goal Right': Virtue and Phronesis in Aristotle's Ethics“, Phronesis 56, s. 204-261.

O'Connor, D. K., 1999, „The Ambitions of Aristotle's Audience and the Activist Ideal of Happiness", in: Bartlett, R. C., Collins, S. D. (ed.), Action and Contemplation. Studies in the Moral and Political Thought of Aristotle, New York, s. 107-129.

Pakaluk, M., 2005, Aristotle's Nicomachean Ethics, Cambridge.

Platón, 1992, Gorgias, přeložil František Novotný, Praha.

Platón, 1994, Euthyfrón. Obrana Sókrata. Kritón, přeložil František Novotný, Praha.

Platón, 1996, Ústava, přeložil František Novotný, Praha.

Rorty, A., 1978, „The Place of Contemplation in Aristotle's Nicomachean Ethics“, Mind 87, s. 343-358.

Synek, S., 2011, Lidská přirozenost jako úkol člověka. Filosofická interpretace Etiky Nikomachovy, Praha.

Urmson, J. O., 1995, Aristotle's Ethics, Oxford.

Xenofón, 1972, Vzpominky na Sókrata, přeložil Václav Bahník, Praha. 